\title{
VITAMIN C IN NEUROPSYCHIATRY
}

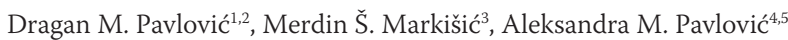

${ }^{1}$ Faculty for special education and rehabilitation, University of Belgrade, Belgrade, Serbia

${ }^{2}$ Faculty of Philosophy, Department of Psychology, University of Belgrade, Belgrade, Serbia

${ }^{3}$ General Hospital, Unit of Neurology, Berane, Montenegro

${ }^{4}$ Faculty of Medicine, University of Belgrade, Belgrade, Serbia

${ }^{5}$ Neurology Clinic, Clinical Center of Serbia, Belgrade, Serbia

VITAMIN C U NEUROPSIHIJATRIJI

Dragan M. Pavlovićc ${ }^{1,2}$, Merdin Š. Markišić ${ }^{3}$, Aleksandra M. Pavlovićt,

Fakultet za specijalnu edukaciju i rehabilitaciju Univerziteta u Beogradu, Beograd, Srbija

${ }^{2}$ Filozofski fakultet Univeziteta u Beogradu, Odeljenje za psihologiju, Beograd, Srbija

3 Opšta Bolnica Berane, Crna Gora

${ }^{4}$ Medicinski fakultet Univerziteta u Beogradu, Beograd, Srbija

${ }^{5}$ Neurološka klinika Kliničkog centra Srbije, Beograd, Srbija

Financial disclosure:

This article is partially financed by the Ministry of Science, Republic of Serbia, Project No 175033 and 175022

Received / Primljen: 26. 12. 2013.

Accepted / Prihvaćen: 28. 02. 2014.

\begin{abstract}
Vitamins are necessary factors in human development and normal brain function. Vitamin $C$ is a hydrosoluble compound that humans cannot produce; therefore, we are completely dependent on food intake for vitamin C. Ascorbic acid is an important antioxidative agent and is present in high concentrations in neurons and is also crucial for collagen synthesis throughout the body. Ascorbic acid has a role in modulating many essential neurotransmitters, enables neurogenesis in adult brain and protects cells against infection. While SVCT1 enables the absorption of vitamin $C$ in the intestine, SVCT2 is primarily located in the brain.

Ascorbate deficiency is classically expressed as scurvy, which is lethal if not treated. However, subclinical deficiencies are probably much more frequent. Potential fields of vitamin $C$ therapy are in neurodegenerative, cerebrovascular and affective diseases, cancer, brain trauma and others. For example, there is some data on its positive effects in Alzheimer's disease. Various dosing regimes are used, but ascorbate is safe, even in high doses for protracted periods. Better designed studies are needed to elucidate all of the potential therapeutic roles of vitamin $C$.
\end{abstract}

Key words: vitamin C, neurotransmitters, antioxidant, collagen

\section{INTRODUCTION}

Some of the functions of vitamins in neurological and psychiatric diseases are well known (1). The growing body of evidence shows novel roles of vitamins, such as vitamins $\mathrm{B}, \mathrm{D}$ and $\mathrm{A}$, in the brain, with important neuropsychiatric implications (2). Vitamin C (ascorbic acid, ascorbate) is a hydrosoluble vitamin that is not produced in humans. Vitamin C was isolated in the early 1930s. Albert Szent-Györgyi won the Nobel Prize in 1937 for his discovery of vitamin C, and Linus Pauling, a double Nobel laureate, popularized its use for disease prevention and longevity (3).

\section{SAŽETAK}

Vitamin su neophodni faktori za razvoj i normalnu funkciju mozga kod ljudi. Vitamin C je hidrosolubilno jedinjenje koje ljudski organizam ne može da sintetiše tako da smo potpuno zavisni od unosa putem hrane. Askorbinska kiselina je važno antioksidativno sredstvo i prisutna je u neuronima u visokim koncentracijama. Takođe je od ključnog značaja za sintezu kolagena u celom organizmu. Askorbinska kiselina ima ulogu u modulaciji mnogih bitnih neurotransmitera, omogućava neurogenezu u mozgu odraslog i štiti ćelije od infekcije. Dok SVCT1 omogućava apsorpciju vitamina C u crevima, SVCT2 se nalazi uglavnom u mozgu.

Nedostatak askorbata klasično se ispoljava kao skorbut koji je letalan ako se ne leči, ali je supklinička deficijencija verovatno mnogo češća. Potencijalni terapijski domeni vitamina $C$ terapije su neurodegenerativne, cerebrovaskularne $i$ afektivne bolesti, karcinomi, traume mozga i drugi. Postoje na primer podaci o pozitivnim efekatima askorbinske kiseline u Alchajmerovoj bolesti. Koriste se razni režimi doziranja, ali je askorbat pokazao bezbednost čak $i$ u visokim dozama tokom dugih perioda. Potrebne su bolje dizajnirane studije da se razjasne sve potencijalne terapijske uloge vitamina $C$.

Ključne reči: vitamin $C$, neurotransmiteri, antioksidansi, kolagen 


\section{METABOLISM}

Vitamin C is synthesized from glucose by many animals, with the exception of humans and some other species that are unable to synthesize this vitamin due to enzyme mutations that make them dependent on food resources (4). With oral vitamin $C$ intake, the plasma and tissue concentrations are strictly controlled by absorption, tissue accumulation, renal reabsorption and the rate of utilization, which maintains plasma concentrations up to $100 \mathrm{mmol} / \mathrm{l}$. With supplementation, the plasma concentrations do not exceed 250 $\mathrm{mmol} / \mathrm{l}$ and are frequently less than $150 \mathrm{mmol} / \mathrm{l}$ (6).

Normally, the whole-body vitamin C content is approximately $20 \mathrm{mg} / \mathrm{kg}$, or $1500 \mathrm{mg}$ (7). In restricted intake, ascorbic acid is lost at a rate of $3 \%$ of the whole-body content per day. Plasma ascorbate levels between 20 and 80 $\mathrm{mmol} / \mathrm{l}$ are considered normal. Leukocyte ascorbate is a better indicator of vitamin $C$ status than the plasma levels.

The oxidized form of ascorbate is dehydroascorbic acid (DHA), which is transported to and from the cells via facilitated diffusion through the ubiquitous GLUT family (GLUTs) glucose transporters (5). In cells, DHA is reduced to ascorbate. The ascorbate transporters sodium-dependent vitamin C transporter 1 and 2 (SVCT1 and SVCT2) are fundamental for controlling the pools and cellular contents of vitamin C (8). SVCT1 enables vitamin $C$ absorption in the intestine. Ascorbate cannot cross the blood-brain barrier unless it is converted to DHA. SVCT2 is primarily located in the brain and neuroendocrine tissues, enabling intracellular neuronal concentrations to be increased 20- to 60-fold compared to the plasma concentration. It is a potential protective factor in brain capillary endothelial cells under ischaemia (9). SVCT2 is also present in the peripheral nervous tissue, where it promotes myelination through the formation of the extracellular matrix (10). Trials with vitamin $C$ in Charcot-Marie-Tooth type 1 A patients did not show any benefit $(11,10)$. Ascorbic acid is important for the hydroxylation of lysine and proline residues in the collagen in connective tissues (12).

Vitamin $\mathrm{C}$ is an important regulator of intracellular redox status by maintaining sulphydryl compounds, particularly glutathione, in their reduced state (13). It can repair protein hydroperoxides by regenerating the parent amino acids through reduction. Free radicals convert ascorbic acid to DHA, which is reconverted via the glutathione enzyme complex. Vitamin $C$ can regenerate other antioxidants, such as vitamin E, and protects folic acid. Vitamin C reduces copper and iron.

\section{VITAMIN C DEFICIENCY}

Scurvy is the manifestation of vitamin C deficiency and is a potentially fatal disease. It has been recognized for many centuries. Patients demonstrate pain in the extremities from a failure of osteoid formation, easily occurring gingival bleeding and other haemorrhagic manifestations, as well as hair and tooth loss, swelling, ulcerations, and ultimately death (4). Pseudoparalysis of the limbs occurs because of the extreme pain upon movement caused by haemorrhages under the periosteum. The early signs of vitamin $C$ deficiency are impaired wound healing due to collagen-related pathology, follicular hyperkeratosis, petechial haemorrhages and low plasma and leukocyte concentrations. The lowest physiological requirement is approximately $10 \mathrm{mg} /$ day. Symptoms occur when ingestion falls lower than $10 \mathrm{mg} /$ day or when the whole-body content falls under $300 \mathrm{mg}(4)$.

Between 1988 and 1994 in the United States of America, approximately $15 \%$ of adults were vitamin $\mathrm{C}$-deficient with plasma levels less than $11 \mathrm{mmol} / \mathrm{L}$, which was likely predominantly caused by being overweight (14).

The main foods with higher levels of ascorbic acid are fruit and vegetables, but many people take vitamin C supplements. To correct all signs and symptoms of ascorbic acid deficiency, it is necessary for the whole-body vitamin C level to reach $1000 \mathrm{mg}$ (7).

\section{VITAMIN C AND THE BRAIN}

Vitamin C is crucial for brain function. Some evidence shows that vitamin $C$ is active during brain development in stem cell division, neuronal and glial differentiation, maturation, and neurotransmission $(15,5)$. On the other hand, vitamin $\mathrm{C}$ deficiency impairs folic acid metabolism and presents the clinical manifestation of folic hypovitaminosis during pregnancy (15). Brain ascorbate concentrations are higher in the CSF than in plasma.

Ascorbic acid from the blood accumulates in the brain and is maintained at high concentrations in neuronal and glial cells (16). The ascorbate content in glial cells is substantially lower than in neurons. Ascorbate has different actions from other antioxidants, such as vitamin $\mathrm{E}$ and glutathione (GSH). The newly discovered functions for ascorbate are its role as a co-factor in several important enzyme reactions. Vitamin $C$ reduces oxidative neuronal stress by protecting cell membranes and DNA, reducing beta-amyloid toxicity and regenerating other antioxidants, such as vitamin $\mathrm{E}$ (17).

The regional distribution of ascorbate in the brain is asymmetrical. Vitamin $\mathrm{C}$ acts as a neuromodulator of glutamatergic, dopaminergic, cholinergic and GABAergic transmission and the corresponding behaviours (5). Ascorbate mediates acetylcholine and catecholamine release from synaptic vesicles. Intracellular ascorbate is essential for the protection from oxidant stress.

The role of vitamin $C$ in cognition, mood and behaviour has been most extensively studied in memory and locomotor activity in animal models. Age-related and toxic memory deficits in mice have been reversed by intraperitoneal ascorbate (18). Another effect is anxiety reduction (5). There are also some inconclusive studies about vitamin C's cognitive effects. Acute vitamin C and D deficiency is highly prevalent among patients in acute care (19), and these patients often have mood disturbance and cognitive dysfunction due to these hypovitaminoses. In a random- 
ized, double-blind study of short-term $1000 \mathrm{mg}$ vitamin C supplementation was associated with a $71 \%$ reduction in mood disturbance and a $51 \%$ reduction in psychological distress with the normalization of vitamin $C$ plasma levels. However, daily 5000 IU vitamin D intake increased the plasma levels, but not to the normal level, and did not improve mood or decrease distress (19).

As oxidative stress is involved in the pathophysiology of neurodegenerative diseases, ascorbic acid has therapeutic potential in ischaemic stroke, Alzheimer's disease (AD), Parkinson's disease and Huntington's disease. It protects neurons from glutamatergic excitotoxicity. In many studies, ascorbic acid protected cerebral tissue, which was attributed to its antioxidant capacity (20). In an experimental model, vitamin C dose-dependently inhibited interleukin-1 $\beta$ (IL-1 $\beta$ )-mediated PGE2 synthesis in a human neuronal cell line, which was increased synergistically in combination with aspirin (20).

The main etiopathogenetic factor in Alzheimer's disease is amyloid beta, which is derived from the amyloid precursor protein (APP) and exists in an oligomeric soluble form as well as in deposits called senile plaques (21). The physiological role of APP is different after cleavage of the N-terminal ectodomain, which acts as a growth factor, while the C-terminal endodomain has a role in cell adhesion and gene regulation (22). It is not clear whether amyloid beta has any physiological roles. Vitamin $C$ plasma and CSF levels are reduced in AD despite regular nutrition and supplement intake reduces the AD incidence (5).

Data from the Cache County Study showed that use of vitamin $\mathrm{E}$ and vitamin $\mathrm{C}$ supplements in combination reduces the prevalence and incidence of Alzheimer's disease (23). Additional analysis from the same study showed that higher vitamin $\mathrm{C}$ intake alone was associated with higher cognitive function at baseline on a Modified Mini-Mental State examination (3MS) and the patients had lesser cognitive decline compared with those with lower vitamin C intake (24).

Oxidative stress causes lipid peroxidation in neuronal membranes; the reactive products have cytotoxic and genotoxic properties that alter proteins and DNA and interact with other risk factors to promote neurodegeneration leading to $\mathrm{AD}$ (25). Ascorbate is involved in oligosaccharide metabolism and could preclude the formation of toxic amyloid beta oligomers, which are potentially produced in excess with lower plasma levels of vitamin $C$ (22). In a study of patients with moderate $A D$, the CSF: plasma ascorbic acid ratio predicted cognitive decline, possibly as an index of vitamin C availability to the brain (17). The use of combined antioxidants (vitamins $C$ and $E$ as well as non-steroidal anti-inflammatory drugs) in elderly patients in the Cache County Study had a protective effect on cognitive decline and the development of Alzheimer's disease, but only in participants with the APOE epsilon 4 allele (26).

In a murine model of $\mathrm{AD}$, the addition of vitamin $\mathrm{C}$ can improve spatial learning (27). A meta-analysis of the large population-based studies using a self-reported questionnaire produced inconclusive results, with the majority unable to decisively confirm the association of ascorbate intake or supplementation and $\mathrm{AD}$. However, there were considerable meth- odological limitations (25). Avoiding vitamin C deficiency with adequate food intake is more beneficial than taking supplements, but more well-designed studies are needed (28). The likely scenario in $\mathrm{AD}$ is that there is a shortage of vitamin $\mathrm{C}$. Therefore, the brain uses ascorbate from the peripheral pools to ensure the adequate antioxidant capacity of the brain and reduce the oxidative stress involved in AD pathophysiology (25).

Very high doses of vitamin $C$ have been shown to be toxic to tumour cells in clinical and experimental studies (29). Pharmacologic ascorbate has cytotoxic properties against cancer cells in experimental murine brain tumour (glioblastoma) models (6).

Oxidative injury is considered to be an important pathogenic mechanism in Parkinson's disease, with severe decreases in dopaminergic transmission. Ascorbate improves the bioavailability of levodopa and partially protects dopaminergic neurons from MPTP toxicity (5).

Ischaemic small vessel disease of the brain with white matter lesions correlates with cognitive status in both older and younger populations (30). Common vascular risk factors are present, but some risk factors still unknown. Vitamin $\mathrm{C}$ may have favourable actions in ischemic brain disease as well. A meta-analysis of prospective studies revealed a significant inverse association between dietary vitamin $C$ intake, blood levels of vitamin $C$ and stroke risk (31). Data about ascorbic acid supplements are sparse. The likely mechanisms are its strong antioxidant action, anti-inflammatory action, inhibition of smooth muscle proliferation, membrane protection but also its blood pressure-lowering effects that slow the progression of atherosclerosis (31).

In patients with severe head injury, administration of high doses (up to 10 grams) of vitamin C led to a significant stabilization of the perilesional edema and a reduction of hospital mortality (32).

In adults, neurogenesis only occurs in limited, but crucial brain areas (the hippocampus, olfactory bulb, periventricular area and subependymal hypothalamus) (1). It is of utmost importance that vitamin $C$ is present in adequate quantities for stem cell generation, proliferation and differentiation (33). It is also crucial for neural stem cell generation, proliferation and differentiation during embryonic development.

\section{INDICATIONS AND DOSING}

The recommended dietary allowance (RDA) is primarily based on the prevention of deficiency disease and not on prevention of chronic disease. The RDAs are listed below.

\section{Infants}

0-6 months $40 \mathrm{mg} /$ day

7-12 months $50 \mathrm{mg} /$ day

\section{Children}

$1-3$ years $15 \mathrm{mg} /$ day

4-8 years $25 \mathrm{mg} /$ day

9-13 years $45 \mathrm{mg} /$ day

Adolescents 14-18 years

Males 75 mg/day Females 65 mg/day 


\section{Adults 19 years and older}

Male non-smokers 90 mg/day Female non-smokers 75 mgMale smokers $125 \mathrm{mg} /$ day

Female smokers $110 \mathrm{mg} /$ day In pregnancy

up to 18 years $80 \mathrm{mg} /$ day

19 years or older $85 \mathrm{mg} /$ day

While breast feeding

up to 18 years $115 \mathrm{mg} /$ day and

19 years or older $120 \mathrm{mg} /$ day

Higher doses (400 mg/day or more) of vitamin C supplementation may be cardioprotective (34). The effects on brain disease have been presented above. The brain is the most difficult organ to deplete of ascorbate. Ascorbic acid inhibits the synthesis of some animal carcinogens in the gastric contents at doses of approximately $1000 \mathrm{mg}$ per day (35). Many studies have tested the potential of vitamin C as a chemotherapeutic agent using intravenous doses of up to 65 grams, but the results are controversial. Even with such high doses, the side effects are minimal and primarily include diarrhoea. There are absorption-limiting factors in the intestine, which raises questions about the utility of high dose vitamin C supplementation (28).

There is some evidence that vitamin $C$ intake can reduce the prevalence of cataracts (36). Other possible therapeutic areas are type 2 diabetes, immune disturbances, adrenal hormone disorders, tumours, depression, neurodegenerative disorders, motoneuron disease, the common cold, antagonizing the negative effects of nicotine on the vascular system, promoting wound healing, combating complex regional pain syndrome, arterial hypertension, osteoarthritis and others (5).

\section{SAFETY}

Hypervitaminosis $\mathrm{C}$ is very mild (diarrhoea of osmotic origin in doses over $10 \mathrm{~g}$ per day) and occurs if large doses are taken for many years; therefore, vitamin $C$ is practically non-toxic. However, toxicity has been observed when doses of 3,000 mg per day or higher were taken at once (37). Symptoms can be circumvented by taking buffered salt and not free acid. For instance, doses of $10,000 \mathrm{mg}$ per day have been taken for more than a year without any side effects (38). Some phenomena, such as conditioned scurvy, oxalate or urate kidney stones and pro-oxidant effects, have not been confirmed (39). Vitamin B12 is crucial for central and peripheral nervous system function (40). The observation that ascorbic acid can destroy vitamin B12 in vitro has been quite concerning, but subsequent studies showed no damage (39). The most frequently used dosages of vitamin $C$ in adults are 100-3,000 mg/day, and some advocate "bowel tolerance" doses in acute viral infections, which are doses slightly lower than those causing diarrhoea (41). Taking ascorbic acid in 3 to 6 daily doses or taking it with food increases abortion.

\section{CONCLUSION}

Vitamin C is crucial for normal development and bodily functions in human adulthood; however, humans are not capable of producing vitamin $\mathrm{C}$. It has many important functions. Ascorbic acid is one of the main antioxidative agents in the human body, particularly the brain. Its deficiency is classically expressed as scurvy, but subclinical deficiencies are probably much more frequent. This opens a potential field of interest for vitamin $C$ therapy in neurodegenerative, cerebrovascular and affective diseases, as well as cancer, brain trauma and others. Various dosing regimes are used; however, ascorbate is safe, even in high doses for protracted periods. Better designed studies are needed to elucidate all of the potential therapeutic roles of vitamin $C$.

\section{REFERENCES}

1. Pavlović DM. Neuropsihologija, bihevioralna neurologija i neuropsihijatrija. Beograd: Orion Art, 2012.

2. Pavlović DM, Pavlović AM. B Vitamins and Dementias. Curr Top 2013;21(1-2):39-48.

3. Nahas R, Balla A.Complementary and alternative medicine for prevention and treatment of the common cold. Can Fam Physician. 2011 Jan;57(1):31-36.

4. World Health Organization and Food and Agriculture Organization of the United Nations. Vitamin and mineral requirements in human nutrition. 2nd edition. Geneva: World Health Organization and Food and Agriculture Organization of the United Nations, 2004.

5. Harrison FE, May JM. Vitamin C function in the brain: vital role of the ascorbate transporter SVCT2. Free Radic Biol Med. 2009 Mar 15;46(6):719-730.

6. Levine M, Padayatty SJ, Espey MG. Vitamin C: a concentration-function approach yields pharmacology and therapeutic discoveries. Adv Nutr. 2011 Mar;2(2):78-88.

7. Kallner A, Hartmann D, Hornig D. Steady-state turnover and body pool of ascorbic acid in man. American Journal of Clinical Nutrition, 1979, 32:530-539.

8. May JM. The SLC23 family of ascorbate transporters: ensuring that you get and keep your daily dose of vitamin C. Br J Pharmacol. 2011 Dec;164(7):1793-801.

9. Gess B, Sevimli S, Strecker JK, Young P, Schäbitz WR. Sodium-dependent vitamin C transporter 2 (SVCT2) expression and activity in brain capillary endothelial cells after transient ischemia in mice. PLoS One. 2011 Feb 11;6(2):e17139.

10. Gess B, Röhr D, Young P. Ascorbic acid and sodiumdependent vitamin $\mathrm{C}$ transporters in the peripheral nervous system: from basic science to clinical trials. Antioxid Redox Signal. 2013 Dec 10;19(17):2105-2114.

11. Verhamme C, de Haan RJ, Vermeulen M, Baas F, de Visser M, van Schaik IN. Oral high dose ascorbic acid treatment for one year in young CMT1A patients: a randomised, double-blind, placebo-controlled phase II trial. BMC Med. 2009 Nov 12;7:70. 
12. Jacob RA. Vitamin C. In: Shils ME, Olson Ja, Shike M, eds. Modern nutrition in health and disease, 8th ed. Philadelphia: Lea and Febiger, 1994; 432-448.

13. El-Sokkary GH Awadalla EA. The protective role of vitamin $C$ against cerebral and pulmonary damage induced by cadmium chloride in male adult albino rat. The Open Neuroendocrinology Journal, 2011, 4, 1-8.

14. Hampl JS, Taylor CA, Johnston CS: Vitamin C deficiency and depletion in the United States: the Third National Health and Nutrition Examination Survey, 1988-1994. Am J Pub Health 2004, 94:870-875.

15. Ramakrishna T. Vitamins and brain development. Physiol Res. 1999;48(3):175-187.

16. Rice, M.E., Russo-Menna, I. 1998. Differential compartmentalization of brain ascorbate and glutathione between neurons and glia. Neuroscience 82, 1213-1223.

17. Bowman GL, Dodge H, Frei B, Calabrese C, Oken BS, Kaye JA, Quinn JF. Ascorbic acid and rates of cognitive decline in Alzheimer's disease. J Alzheimers Dis. 2009;16(1):93-8

18. Parle M, Dhingra D. Ascorbic Acid: a promising memory-enhancer in mice. J Pharmacol Sci 2003;93:129-135.

19. Wang Y, Liu XJ, Robitaille L, Eintracht S, MacNamara E, Hoffer LJ. Effects of vitamin C and vitamin D administration on mood and distress in acutely hospitalized patients. Am J Clin Nutr 2013;98(3):705-11.

20. Candelario-Jalil E, Akundi RS, Bhatia HS, Lieb K, Appel K, Muñoz E, Hüll M, Fiebich BL. Ascorbic acid enhances the inhibitory effect of aspirin on neuronal cyclooxygenase-2-mediated prostaglandin E2 production. J Neuroimmunol. 2006 May;174(1-2):39-51.

21. Pavlovic DM, Pavlovic AM, Žugić S. Patogeneza Alzheimerove bolesti. Vojnosanit Pregl. 2007 Nov;64(11):765-772.

22. Cheng F, Cappai R, Ciccotosto GD, Svensson G, Multhaup G, Fransson LA, Mani K. Suppression of amyloid beta A11 antibody immunoreactivity by vitamin C: possible role of heparan sulfate oligosaccharides derived from glypican-1 by ascorbate-induced, nitric oxide (NO)-catalyzed degradation. J Biol Chem. 2011 Aug 5;286(31):27559-72.

23. Zandi PP, Anthony JC, Khachaturian AS, Stone SV, Gustafson D, Tschanz JT,Norton MC, Welsh-Bohmer KA, Breitner JC; Cache County Study Group. Reduced risk of Alzheimer disease in users of antioxidant vitamin supplements: the Cache County Study. Arch Neurol. 2004 Jan;61(1):82-88

24. Wengreen HJ, Munger RG, Corcoran CD, Zandi P, Hayden KM, Fotuhi M, et al. Antioxidant intake and cognitive function of elderly men and women: the Cache County Study. J Nutr Health Aging. 2007 MayJun;11(3):230-237.

25. Bowman GL. Ascorbic acid, cognitive function, and Alzheimer's disease: a current review and future direction. Biofactors. 2012 Mar-Apr;38(2):114-122

26. Fotuhi M, Zandi PP, Hayden KM, Khachaturian AS, Szekely CA, Wengreen $\mathrm{H}$, et al. Better cognitive perfor- mance in elderly taking antioxidant vitamins $\mathrm{E}$ and $\mathrm{C}$ supplements in combination with nonsteroidal anti-inflammatory drugs: the Cache County Study. Alzheimers Dement. 2008 May;4(3):223-227.

27. Harrison FE, Hosseini AH, McDonald MP, May JM. Vitamin $C$ reduces spatial learning deficits in middle-aged and very old APP/PSEN1 transgenic and wild-type mice. Pharmacol Biochem Behav. 2009 Oct;93(4):443-450.

28. Harrison FE. A critical review of vitamin C for the prevention of age-related cognitive decline and Alzheimer's disease. J Alzheimers Dis. 2012;29(4):711-726.

29. Riordan NH, Riordan HD, Casciari JP. Clinical and experimental experiences with Intravenous Vitamin C. Journal of Orthomolecular Medicine 2000 Vol. 15, No. 4, 201-213.

30. Pavlović AM, Pekmezović T, Zidverc-Trajković J, Jovanović Z, Mijajlovic M, Pavlović D, Tomić G, Sternić $\mathrm{N}$. What are the differences between younger and older patients with symptomatic small vessel disease? Clin Neurol Neurosurg. 2011;113(9):762-767.

31. Chen GC, Lu DB, Pang Z, Liu QF. Vitamin C intake, circulating vitamin $C$ and risk of stroke: a meta-analysis of prospective studies. J Am Heart Assoc. 2013 Nov 27;2(6):e000329.

32. Razmkon A, Sadidi A, Sherafat-Kazemzadeh E, MD, Mehrafshan A, Jamali M, Malekpour B, Saghafinia M. Administration of Vitamin $\mathrm{C}$ and Vitamin $\mathrm{E}$ in Severe Head Injury: A Randomized Double-blind Controlled Trial. Clinical Neurosurgery 2011; 58, 133-137.

33. Pastor P, Cisternas P, Salazar K, Silva-Alvarez C, Oyarce K, Jara N, Espinoza F, Martínez AD, Nualart F. SVCT2 vitamin $\mathrm{C}$ transporter expression in progenitor cells of the postnatal neurogenic niche. Front Cell Neurosci. 2013 Aug 13;7:119.

34. Ye Z, Song H. Antioxidant vitamins intake and the risk of coronary heart disease: meta-analysis of cohort studies. Eur J Cardiovasc Prev Rehabil 2008;15(1):26-34.

35. Food and Drug Administration. Food labeling: Health claims and label statements: Antioxidant vitamins and cancer; final rule. Federal register 1993; 58:2622-2660.

36. Thiagarajan R, Manikandan R.Antioxidants and cataract. Free Radic Res. 2013 May;47(5):337-45.

37. Miller DR, Hayes KC. Vitamin excess and toxicity. In: Hathcock JN, ed. Nutritional toxicology, vol. 1. New York: Academic Press, 1982; 81-133.

38. Bendich A, Langseth L. The health effects of vitamin C supplementation: A review. J am Coll Nutr 1995; 14:124-136.

39. Food and Nutrution Board. Dietary reference intakes for vitamin $C$, vitamin $E$, selenium, and carotenoids. Washington, DC: National Academy Press, 2000.

40. Pavlović DM, Pavlović AM. Deficit vitamina B12 u neurologiji. Srp arh celok lek 2003;131:412-418.

41. Cathcart RF. Vitamin C: the nontoxic, nonrate-limited, antioxidant free radical scavenger. Med Hypotheses 1985;18:61-77. 